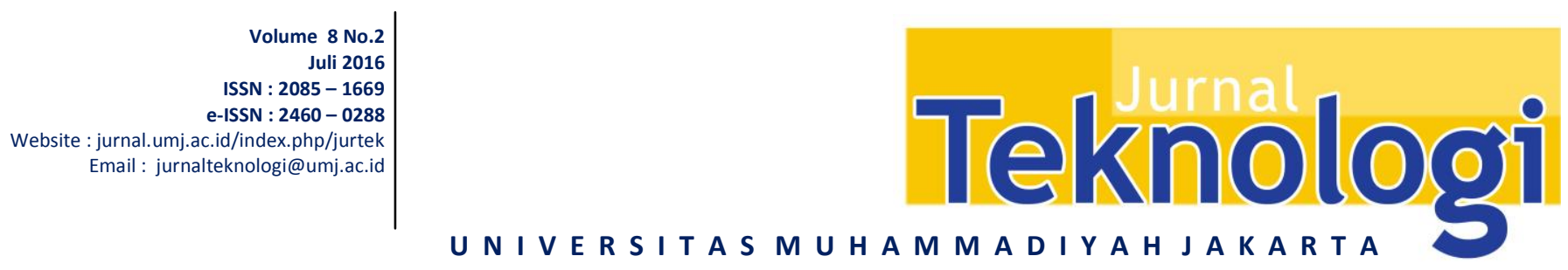

\title{
ANGKA LEMPENG TOTAL (ALT), ANGKA PALING MUNGKIN (APM) DAN TOTAL KAPANG KHAMIR SEBAGAI METODE ANALISIS SEDERHANA UNTUK MENENTUKAN STANDAR MIKROBIOLOGI PANGAN OLAHAN POSDAYA
}

\author{
Yoni Atma ${ }^{1 *}$ \\ ${ }^{1}$ Program Studi Ilmu dan Teknologi Pangan, Universitas Trilogi, Jakarta \\ Kampus Trilogi, Jalan TMP. Kalibata No. 1 Kalibata-Jakarta Selatan 12760 Indonesia \\ *Email: yoniatma@universitas-trilogi.ac.id
}

\begin{abstract}
ABSTRAK
Penelitian ini dilakukan untuk menganalisa mutu mikrobiologi makanan olahan posdaya. Parameter yang dianalisia antara lain: total mikroba atau angka lempeng total, keberadaan bakteri koliform serta total kapang dan khamir. Sampel produk posdaya yang dianalisa adalah produk makanan olahan yang berada di posdaya Mawar Setu Cipayung Jakarta Timur seperti jahe instan, manisan jahe, jus wornas dan jelly. Hasil penelitian menunjukkan bahwa jahe instan memiliki nilai total mikroba 5,5x10 $\mathrm{CFU} / \mathrm{g}$, koliform $<3 \mathrm{APM} / \mathrm{g}$ dan kapang khamir $3 \times 10^{1}$ CFU/g. Manisan jahe mengandung total mikroba $7 \times 10^{1} \mathrm{CFU} / \mathrm{g}$, koliform $<3 \mathrm{APM} / \mathrm{g}$ dan kapang

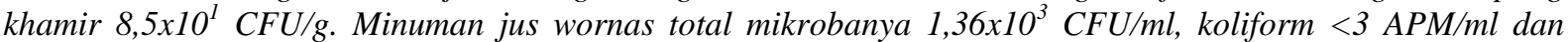

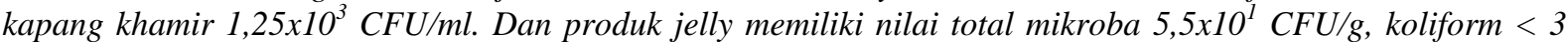

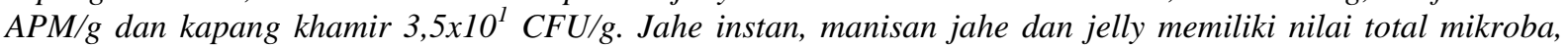
koliform dan kapang khamir yang sesuai dengan standar. Jus wornas memiliki nilai total mikroba yang melewati standar SNI dan total kapang khamir yang melewati standar yang ditetapkan BPOM dan SNI.
\end{abstract}

Kata kunci: mutu mikrobiologi, pangan olahan posdaya, total mikroba, koliform, kapang khamir

\begin{abstract}
The aims of this study was to find of microbiology quality on posdaya's foods. The parameters that analyzed was aerobic plate count, coliform and mould yeast count. The sample is processed foods in posdaya Mawar Setu Cipayung East Jakarta such as instant ginger, candied ginger, wornas (pineapple blended carrot) juice and jelly. The result shown that instant ginger have aerobic plate count value 5,5x10 $\mathrm{CFU} / \mathrm{g}$, coliform $<3 \mathrm{MPN} / \mathrm{g}$ and mould yeast $3 \times 10^{1} \mathrm{CFU} / \mathrm{g}$. Aerobic plate count of candied ginger is $7 \times 10^{1} \mathrm{CFU} / \mathrm{g}$, coliform $<3 \mathrm{MPN} / \mathrm{g}$ and mould yeast $8,5 \times 10^{1} \mathrm{CFU} / \mathrm{g}$. Wornas juice is $1,36 \times 103 \mathrm{CFU} / \mathrm{ml}$ in aerobic plate count, coliform $<3 \mathrm{MPN} / \mathrm{ml}$ and

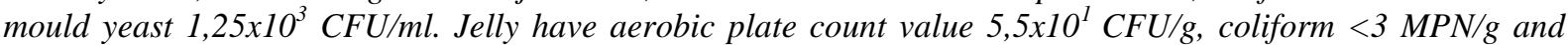

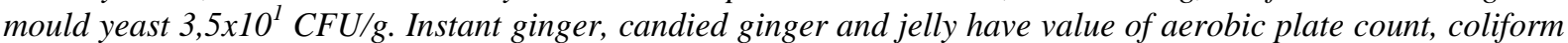
and mould yeast count that conform with standard. The wornas juice have aerobic plate count value that exceed National Standardization Agency of Indonesia (SNI) and mould yeast value that exceed SNI and The National Agency of Drug and Food Control (NA-DFC).
\end{abstract}

Keywords:quality of microbiology, posdaya's foods, aerobic plate count, coliform, mould yeas

\section{PENDAHULUAN}

Posdaya adalah forum silaturahmi, advokasi, dan komunikasi untuk meningkatkan fungsi keluarga secara terpadu dengan melibatkan masyarakat dalam suatu organisasi kelembagaan
(Suyono \& Haryanto, 2013). Posdaya mengembangkan berbagai bidang potensial dalam upaya peningkatan kesejahteraan keluarga. Salah satu bidang pengembangan posdaya adalah wirausaha. Bidang wirausaha di posdaya dapat 
memberikan manfaat langsung terhadap kesejahteraan keluarga melalui keuntungan dari pendapatan penjualan yang diperoleh.

Wirausaha posdaya antara lain seperti penjualan tas, dompet, baju dan souvenir, penjualan buah dan sayur dari hasil kebun bergizi serta aneka pangan olahan. Biasanya produk makanan olahan posdaya merupakan makanan lokal yang dibuat karena tradisi (kebiasaan) masyarakat setempat. Selain itu, juga karena potensi bahan baku pangan yang dimiliki dan beberapa karena kepandaian masyarakat atau anggota posdaya dalam membuat makanan olahan tertentu (Yodfi et al. 2015).

Jus wortel nanas (wornas), jahe instan, manisan jahe, dan jelly merupakan produk pangan hasil olahan dari Posdaya Mawar Setu, Cipayung Jakarta Timur. Produk-produk ini telah dijual ke masyarakat sekitar dan beberapa ke luar kota. Jus wornas, jahe instan, manisan jahe dan jelly juga disediakan pada berbagai kegiatan-kegiatan yang diikuti dan dilaksanakan oleh posdaya seperti gelanggang dagang, pameran bagi Industri Kecil dan Menengah (IKM), menyambut tamu, observation study tour (OST) dan lain-lain. Akan tetapi seperti halnya produk makanan olahan dari posdaya-posdaya lainnya, produk-produk ini masih belum memiliki nilai mutu yang terukur. Menurut Syah (2012), mutu pangan antara lain meliputi mutu fisik dan sensori, kimia termasuk nilai gizi serta mikrobiologi. Mutu atau standar mikrobiologi merupakan parameter yang tidak terlihat oleh mata tetapi sangat menentukan keamanan dan daya tahan bahan pangan (Jay, 2006).

Penyimpangan mutu mikrobiologi mengakibatkan produk pangan tidak layak dipasarkan dan dikonsumsi. Banyak penelitian menunjukkan bahwa konsumsi pangan yang nilai mikrobiologinya menyimpang atau melewati standar dapat menyebabkan diare, pusing, muntah, mual dan demam. Bahkan beberapa bakteri tertentu dapat menyebabkan pingsan, kerusakan sel saraf hingga kematian (Ray, 2000). Produk yang standar mikrobiologinya menyimpang akan lebih mudah rusak sehingga umur simpannya menjadi lebih singkat. Selain itu, mutu mikrobiologi juga dijadikan sebagai indikator kebersihan dan higienitas proses produksi (Shewfelt, 2014).

Pemerintah melalui Badan Pengawasan Obat dan Makanan (BPOM) dan Standar Nasional Nasional (SNI) telah mempersyaratkan kriteria mikrobiologi untuk sebagian besar bahan dan produk pangan. Kriteria mikrobiologi pangan bervariasi tergantung dari jenis pangannya. Pada umumnya kriteria analisis produk pangan yaitu nilai total mikroba atau angka lempeng total, total kapang dan khamir, dan bakteri koliform. Pada produk tertentu ada juga yang mempersyaratkan analisis keberadaan bakteri pathogen. Produk pangan yang dipersyaratkan kriteria mikrobiologinya meliputi produk segar, produk olahan siap konsumsi, produk setengah jadi seperti tepung-tepungan dan bahan tambahan pangan (BPOM, 2008).

Proses produksi yang masih sangat sederhana, pengetahuan mengenai higienitas dan kebersihan yang masih sangat terbatas, dan tidak terdapatnya sistem manajemen produksi yang berstandar menjadikan makanan olahan posdaya rentan terhadap resiko keamanan. Oleh karena itu perlu dilakukan analisis tingkat keamanannya terutama aspek mikrobiologi. Pemilihan metode analisis mikrobiologi perlu disesuaikan dan disederhanakan dengan kebutuhan dan kesanggupan industri secara finansial. Karena untuk analisis kriteria mikrobiologi tertentu membutuhkan peralatan dan bahan yang mahal dan modern yang tidak mungkin saat ini dapat disanggupi oleh industri skala rumah tangga.

Usaha pembuatan makanan olahan posdaya merupakan industri skala rumah tangga yang memiliki beberapa kelemahan dan keterbatasan dibandingkan industri makro diantaranya seperti fasilitas pengujian dan keuangan (Atma, et al. 2015). Akan tetapi, persyaratan yang telah ditetapkan mesti diikuti demi kenyamanan dan keamanan konsumen (Antara, 2014). Oleh sebab itu penelitian ini dilakukan untuk menentukan mutu mikrobiologi pangan olahan posdaya dengan analisis metode konvensional yang telah banyak digunakan pada berbagai macam produk. Analisis yang dilakukan antara lain: 1) penentuan jumlah mikroba untuk menetapkan kebersihan proses produksi, 2) analisis koliform untuk menentukan indikator sanitasi dan 3) total kapang khamir untuk mengetahui kerusakan produk kadar air rendah oleh mikroorganisme.

\section{METODOLOGI PENELITIAN}

Penelitian dilaksanakan di laboratorium kimia dan mikrobiologi fakultas Bioindustri Universitas Trilogi, Jakarta Selatan. Bahan yang digunakan antara lain: jus wortel nanas (wornas), jahe instan, manisan jahe, produk jelly, aquades, plate count agar (PCA), potato dextrose agar (PDA), buffer pepton, dan lactose broth (LB), Briliant Green Lactose Bile Broth (BGLBB), dan alkohol $70 \%$. Alat yang digunakan antara lain: refrigerator, waterbath, cawan petri, gelas piala, gelasa ukur, erlenmeyer, tabung reaksi, lampu bunsen, kertas saring, pipet ukur, bulb, inkubator, colony counter, blender, autoklave, timbangan analitik, termometer, spatula dan batang pengaduk.

Tahapan persiapan dan pengenceran sampel jus wornas dilakukan dengan memasukkan (pipeting) sebanyak $15 \mathrm{ml}$ sampel ke dalam botol pengencer yang telah berisi $125 \mathrm{ml}$ larutan buffer pepton (1:10), lalu diaduk hingga homogen. Pengenceran dilakukan hingga $10^{-3}$. Pada produk jahe instan, manisan jahe dan jelly maka persiapan dilakukan dengan menimbang sebanyak $15 \mathrm{~g}$ 
sampel lalu dimasukkan ke dalam botol pengencer yang telah berisi $125 \mathrm{ml}$ larutan buffer pepton (1:10) lalu diaduk hingga homogen. Kemudian dibuat pengenceran hingga $10^{-3}$.

Analisis total mikroba dilakukan dengan mengambil masing-masing sebanyak $1 \mathrm{ml}$ sampel pengenceran dan dimasukkan ke dalam cawan petri steril. Selanjutnya dituangkan media PCA cair ke dalam cawan petri tersebut sebanyak 15-20 ml. Cawan petri dengan hati-hati diputar dan digerakkan horizontal atau sejajar (atau membentuk angka delapan) hingga sampel tercampur rata. Bersamaan dengan itu dilakukan juga pemeriksaan blanko dengan mencampur buffer ke dalam media. Campuran dalam cawan petri selanjutnya dibiarkan membeku. Tahap akhir yaitu inkubasi dengan memasukkan semua cawan petri pada posisi terbalik kedalam inkubator. Inkubasi dilakukan pada suhu $36 \pm 1{ }^{0} \mathrm{C}$ selama $24-48$ jam. Perhitungan dan pencatatan pertumbuhan koloni dilakukan dalam satuan koloni forming unit per gram atau ml sampel (cfu/gr atau ml) (Maturin \& Peeler, 2001).

Analsisi kapang khamir dilakukan dengan memasukkan media PDA cair (suhu $45 \pm 1{ }^{\circ} \mathrm{C}$ ) sebanyak 15-20 ml kedalam cawan petri dan dibiarkan memadat/membeku. Kemudian sebanyak $1 \mathrm{ml}$ sampel yang telah diencerkan dimasukkan ke dalam cawan petri yang telah berisi media PDA padat. Setelah itu, sampel disebar dengan bantuan batang penyebar. Inkubasi dilakukan pada suhu 25 ${ }^{\circ} \mathrm{C}$ selama 3-5 hari. Setelah diinkubasi selama 3-5 hari, maka kemudian dihitung jumlah koloni kapang dan khamir (Maturin \& Peeler, 2001).

Rumus perhitungan total mikroba dan kapang khamir (Harigan, 1998)

$$
\begin{aligned}
A P C \text { atau ALT }= & \underline{[C} \\
& ((1 \times n 1)+(0.1 \times n 2) \times d))
\end{aligned}
$$

Dimana:

$\mathrm{C}=$ adalah jumlah koloni dari tiap-tiap petri

$\mathrm{n} 1$ = adalah jumlah petri dari pengenceran pertama yang dihitung

$\mathrm{n} 2=$ adalah jumlah petri dari pengenceran kedua

$\mathrm{d}=$ adalah pengenceran pertama yang dihitung

Analisis bakteri koliform dilakukan melalui 2 tahap yaitu uji penduga (presumtif test) dan uji penegasan (confirmed test). Pada uji penduga masing-masing sampel hasil pengenceran dimasukkan sebanyak $1 \mathrm{ml}$ ke dalam tabung reaksi yang telah berisi $9 \mathrm{ml}$ Lactose Broth (LB). Didalam tabung ini telah dimasukkan tabung durham sebelumnya. Analisis menggunakan seri 3 tabung. Kemudian dilakukan inkubasi pada suhu $36 \pm 1^{\circ} \mathrm{C}$ selama 24-48 jam. Jika diperoleh hasil positif berupa kekeruhan dan terbentuknya gas, maka dilanjutkan dengan uji penegasan. Uji penegasan dilakukan dengan mengambil 1 ose hasil positif dari uji pendugaan dan dipindahkan kedalam tabung yang berisi $10 \mathrm{ml}$ BGLBB $2 \%$ yang didalamnya juga telah dimasukkan tabung durham terlebih dahulu. Selanjutnya tabung diinkubasi pada suhu $36 \pm 1{ }^{\circ} \mathrm{C}$ selama 24-48. Adanya gas dan kekeruhan pada media BGLBB memperkuat adanya bakteri coliform dalam sampel artinya hasil positif. Kemudian dihitung jumlah tabung positif dan dicatat hasil coliform dalam APM (angka paling mungkin) sesuai dengan tabel perhitungan coliform (Faridah et al., 2013)

\section{HASIL DAN PEMBAHASAN \\ Jahe Instan dan Manisan Jahe}

Jahe (Zingiber officinale) tergolong kedalam kelompok rempah-rempah yang diambil rimpangnya untuk kebutuhan konsumsi. Tanaman ini juga disebut sebagai tanaman obat keluarga karena memiliki berbagai manfaat kesehatannya. Berdasarkan pada manfaat kesehatan dan permintaan konsumen, maka posdaya Mawar Setu pun telah mengolah rimpang jahe menjadi produk bubuk instan dan manisan. Jahe instan adalah produk bubuk yang diperoleh dari penghancuran rimpang jahe dengan prinsip pengeringan atau penurunan kadar air. Pembuatan bubuk instan selain dapat mempermudah transportasi, juga meningkatkan nilai tambah dan umur simpan produk. Jahe instan memiliki umur simpan 18 bulan pada suhu $30{ }^{\circ} \mathrm{C}$ dan 32 bulan pada suhu $25{ }^{\circ} \mathrm{C}$ (Sugiarto et al., 2007). Manisan jahe merupakan produk jahe yang dibuat dengan penambahan gula kemudian dikeringkan. Manisan jahe dapat langsung dikonsumsi seperti permen, dengan rasa yang khas jahe. Produk manisan jahe memiliki kadar air $<30 \%$ sehingga memiliki umur simpan lebih lama. Ada 2 jenis manisan jahe yaitu manisan jahe kering dan manisan jahe basah (Yuriani, 2010).

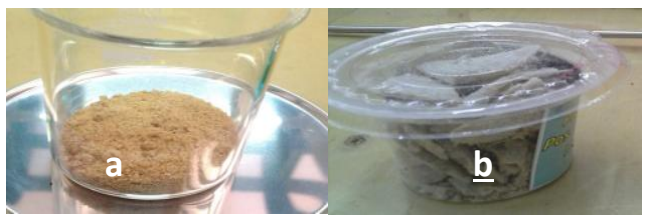

Gambar 1. Produk olahan posdaya Mawar Setu dari rimpang jahe. (a) jahe instan, (b) manisan jahe

Hasil analisis mutu mikrobilogi produk posdaya Mawar Setu jahe instan dan manisan jahe menunjukkan nilai total mikroba, bakteri coliform dan total kapang serta khamir yang sesuai dengan standar yang telah ditetapkan Badan Pengawasan Obat dan Makanan (BPOM) dan Standar Nasional Indonesia (SNI). Secara mikrobiologi produk jahe instan dan manisan jahe aman. Meskipun untuk produk manisan jahe nilai total kapang \& khamir lebih besar dibandingkan standar BPOM yakni 8,5 
x $10^{1} \mathrm{CFU} / \mathrm{g}$ pada produk manisan jahe sedangkan standard BPOM $5 \times 10^{1} \mathrm{CFU} / \mathrm{g}$, tetapi perbedaannya tidak terlalu jauh artinya masih dalam satu log yang sama sehingga manisan jahe yang dihasilkan masih memenuhi standard. Penelitian Faridah et al., (2013) menunjukkan total mikroba produk bandrek instan adalah $25 \times 10^{1} \mathrm{CFU} / \mathrm{g}$ dan koliformnya $<3$ APM $/ \mathrm{ml}$. Pertumbuhan mikroorganisme pada produk berbahan baku jahe bukanlah suatu yang dikhawatirkan karena jahe pada dasarnya memiliki sifat antimikroba. Ekstrak jahe telah digunakan untuk memperpanjang umur simpan ikan kembung (Susanto et al., 2011), dan sari jahe secara nyata menurunkan koloni bakteri pada ikan tongkol (Hijriy, 2015).

Tabel 1. Mikrobiologi jahe instan dan manisan jahe

\begin{tabular}{|l|c|c|c|c|c|c|}
\hline \multirow{2}{*}{ Parameter } & \multicolumn{3}{|c|}{ Jahe Instan } & \multicolumn{3}{c|}{ Manisan Jahe } \\
\cline { 2 - 7 } & Hasil & BPOM & SN & Hasil & BPOM & SNI \\
\hline $\begin{array}{l}\text { Total } \\
\text { mikroba }\end{array}$ & $5,5 \times 10^{1}$ & $3 \times 10^{3}$ & $3 \times 10^{3}$ & $7,0 \times 10^{1}$ & $1 \times 10^{5}$ & - \\
\hline Coliform & $<3$ & $<3$ & $<3$ & $<3$ & $<10$ & - \\
\hline $\begin{array}{l}\text { Kapang \& } \\
\text { Khamir }\end{array}$ & $3 \times 10^{1}$ & $1 \times 10^{2}$ & - & $8,5 \times 10^{1}$ & $5 \times 10^{1}$ &. \\
\hline
\end{tabular}

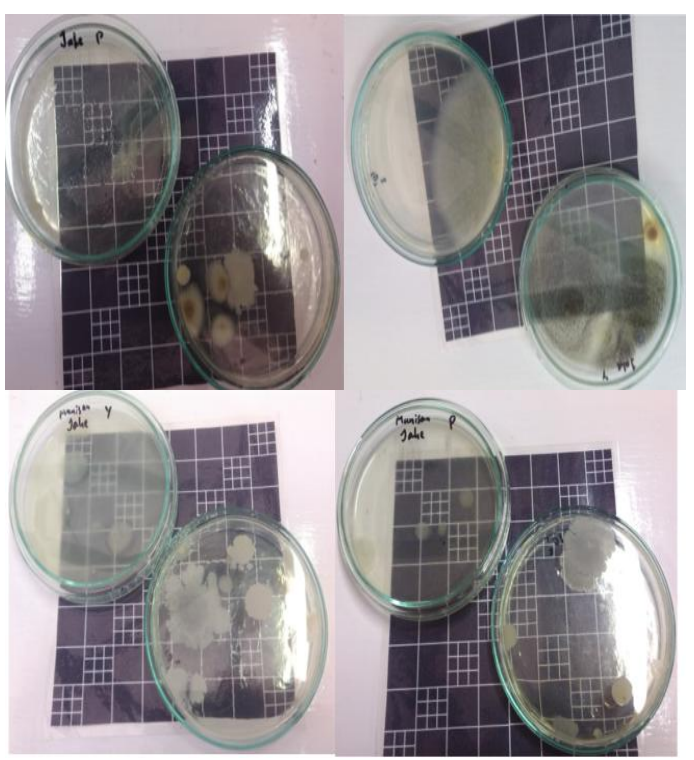

Gambar 2. Cawan analisis total mikroba, kapang khamir produk jahe instan (atas) dan manisan jahe (bawah)

\section{Jus Wor-nas}

Jus wornas merupakan suatu bentuk produk minuman pengembangan dengan tujuan meningkatkan kandungan nutrisi dengan mengkombinasikan wortel sebagai sumber provitamin A dan nanas sebagai sumber vitamin $\mathrm{C}$. Selain itu, jus wornas juga kaya akan serat dan mineral (Pratiwi, 2009). Kombinasi rasa wortel dan nanas menjadikan jus wornas punya rasa yang unik. Jus wornas sudah dapat diterima sebagai variasi minuman baru oleh konsumen. Posdaya Mawar
Setu Cipayung Jakarta Timur manjadikan jus wornas sebagai salah satu produk olahan pangan andalan bidang kewirausahan.

Hasil analisis mikrobiologi jus wor-nas posdaya Mawar Setu menunjukkan koliform yang sesuai dengan standar. Jumlah kapang dan khamir jus wornas melebihi standar yang ditetapkan pemerintah. Jus wornas posdaya mawar setu mengandung kapang \& khamir sebesar $1,25 \times 10^{3}$ $\mathrm{CFU} / \mathrm{ml}$ sedangkan standar yang ditetapkan adalah $1 \times 10^{2} \mathrm{CFU} / \mathrm{ml}$ (BPOM) dan $5 \times 10^{1} \mathrm{CFU} / \mathrm{ml}$ (SNI). Jumlah total mikroba jus wornas jika berdasarkan standar BPOM masih memenuhi standar tetapi jika berdasarkan standar yang ditetapkan oleh SNI, maka total mikroba pada jus wornas posdaya Mawar Setu melewati standar. Standar khusus yang ditetapkan pemerintah memang belum ada untuk jus wornas sehingga acuan standar yang digunakan berdasarkan penggolongan produk. BPOM menggolongkan satu standar yang sama untuk produk jus buah dan jus sayuran sedangkan SNI menggolongkan satu standar yang sama untuk semua minuman sari buah. Produk jus wornas posdaya Mawar Setu bebas dari bakteri koliform tetapi tidak aman dari sisi total mikroba, kapang dan khamir.

Tabel 2. Mikrobiologi produk jus wornas

\begin{tabular}{|l|c|c|c|}
\hline \multirow{2}{*}{ Parameter } & \multicolumn{3}{|c|}{ Jus Wornas } \\
\cline { 2 - 4 } $\begin{array}{l}\text { Total } \\
\text { mikroba }\end{array}$ & $1,36 \times 10^{3}$ & $1 \times 10^{4}$ & $2 \times 10^{2}$ \\
\hline Coliform & $<3$ & $<20$ & $<3$ \\
\hline $\begin{array}{l}\text { Kapang \& } \\
\text { Khamir }\end{array}$ & $1,25 \times 10^{3}$ & $1 \times 10^{2}$ & $5 \times 10^{1}$ \\
\hline
\end{tabular}

Jumlah total mikroba, kapang dan khamir pada jus worna diperkuat dengan bukti-bukti pada saat analisis koliform. Analsis koliform terdiri dari dua tahap yaitu uji penduga dan uji konfirmasi. Pada uji penduga menunjukkan hasil yang positif dimana media lactose broth (LB) keruh dan terdapat gas. Hal ini mengindikasikan terdapat banyak bakteri yang tumbuh. Namun pada saat uji konfirmasi yang menggunakan media spesifik brilliant green lactose bile broth (BGLBB) menunjukkan hasil yang negatif artinya tidak terdapat bakteri koliform pada sampel jus wornas.

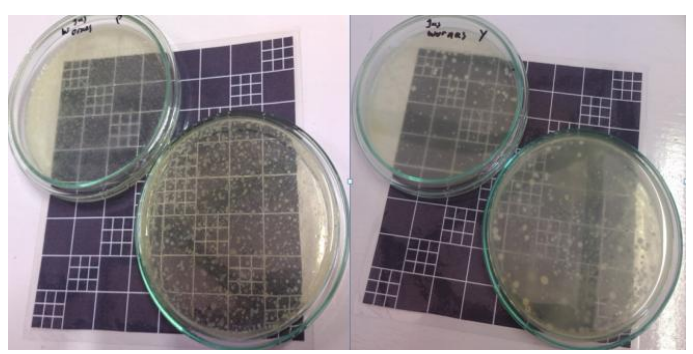

Gambar 3. Cawan analisis total bakteri, kapang dan khamir jus wornas 
Jus merupakan produk yang memiliki kadar air tinggi, sementara itu pertumbuhan mikroba dipengaruhi oleh kadar air dan $\mathrm{a}_{\mathrm{w}}$. $\mathrm{a}_{\mathrm{w}}$ adalah jumlah air bebas yang dibutuhkan oleh mikroorganisme untuk tumbuh dan memperbanyak jumlahnya. Pertumbuhan mikroba juga dipengaruhi oleh $\mathrm{pH}$, $\mathrm{pH}$ jus wornas berkisar antara 3,4-4,3. Mikroorganisme umumnya tumbuh pada kisaran pH 3-6. Selain itu, suhu dan lamanya waktu penyimpanan mempengaruhi jumlah mikroba yang tumbuh (Pratiwi 2009). Penelitian yang dilakukan oleh Pratiwi (2009) menunjukkan bahwa jus wornas yang dibuat dan disimpan pada suhu $5{ }^{\circ} \mathrm{C}$ mengandung total mikroba awal $2,5 \times 10^{2} \mathrm{CFU} / \mathrm{ml}$ dan kemudian meningkat menjadi $6,5 \times 10^{3} \mathrm{CFU} / \mathrm{ml}$ saat disimpan pada suhu $30{ }^{\circ} \mathrm{C}$ selama 4 minggu. Kapang dan khamir jus wornas juga meningkat selama penyimpanan dari awalnya 10 pada suhu 5 dan $30{ }^{\circ} \mathrm{C}$ menjadi $10^{2} \mathrm{CFU} / \mathrm{ml}$ setelah disimpan 2 minggu. Dan akhirnya menjadi $1,6 \times 10^{2} \mathrm{CFU} / \mathrm{ml}$ setelah 4 minggu penyimpanan suhu $30^{\circ} \mathrm{C}$.

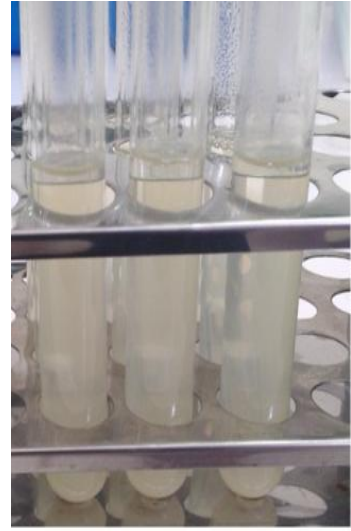

a

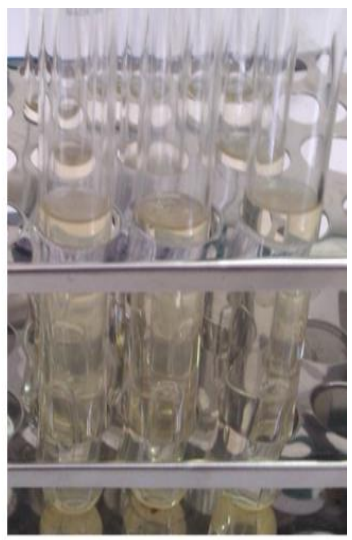

b
Gambar 4. Perbandingan hasil analisis sampel jus wornas (a) dan jahe instan (b) pada media LB Jelly

Jika dibandingkan jahe instan, manisan jahe dan jus wornas, maka jelly tergolong produk baru yang dibuat oleh ibu-ibu posdaya Mawar Setu. Berdasarkan penggolangan bahan pangan sebenarnya jelly yang dibuat di posdaya Mawar Setu adalah jenis agar-agar. Manurut Nugraha (2003), agar-agar adalah polisakarida yang berasal dari hasil pengolahan rumput laut. Agar-agar memiliki keunggulan karena kandungan nutriennya yang cukup bermanfaat bagi kesehatan, terutama karena tingginya kandungan serat (dietary fiber). Agar-agar tidak larut dalam air dingin, tetapi larut dalam air panas. Bahan baku utama yang saat ini digunakan sebagai pembuat agar-agar adalah rumput laut atau ekstrak rumput laut. Rumput laut yang menjadi bahan pembuat agar-agar atau ekstrak agar di Indonesia dan telah banyak dibudidayakan adalah dari genus Eucheuma dan Glacilaria.

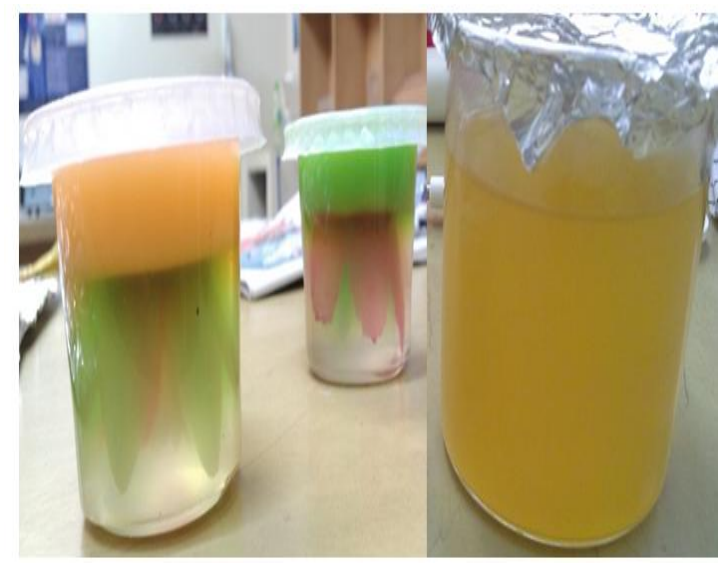

Gambar 5. Jelly (kiri) dan jus wornas (kanan) dalam gelas piala sebelum dianalisis

Hasil analisis mikrobiologi menunjukkan bahwa jelly "jelentik" posdaya Mawas Setu memiliki jumlah total mikroba, koliform serta kapang dan khamir yang sesuai dengan standar yang ditetapkan pemerintah (BPOM dan atau SNI). Standar mutu BPOM yang dijadikan acuan adalah standar mutu mikrobiologi untuk produk jelly agar dan standar SNI yang digunakan adalah SNI 013552-1994 tentang jelly.

Tabel 3. Mikrobiologi produk jelly

\begin{tabular}{|l|l|l|l|}
\hline \multirow{2}{*}{ Parameter } & \multicolumn{3}{|c|}{ Jelly } \\
\cline { 2 - 4 } & \multicolumn{1}{|c|}{ Hasil } & \multicolumn{1}{c|}{ BPOM } & \multicolumn{1}{c|}{ SNI } \\
\hline $\begin{array}{l}\text { Total } \\
\text { mikroba }\end{array}$ & $5,5 \times 10^{1}$ & $1 \times 10^{4}$ & $1 \times 10^{4}$ \\
\hline Coliform & $<3$ & $<3$ & $<20$ \\
\hline $\begin{array}{l}\text { Kapang \& } \\
\text { Khamir }\end{array}$ & $3,5 \times 10^{1}$ & $1 \times 10^{2}$ & $<50$ \\
\hline
\end{tabular}

Penelitian yang dilakukan oleh Kurniawati (2013) pada jelly kulit buah markisa memberikan nilai analisis total mikroba yang bervariasi dari $10^{1}$ sampai $10^{4} \mathrm{CFU} / \mathrm{g}$ dan total kapang khamir $10^{2}$ CFU/g. Minuman agar yang dibuat oleh Nugraha (2003) sebagai upaya diversifikasi pangan berbasis agar-agar memiliki nilai total mikroba $7,5 \times 10^{3}$ $\mathrm{CFU} / \mathrm{g}$.

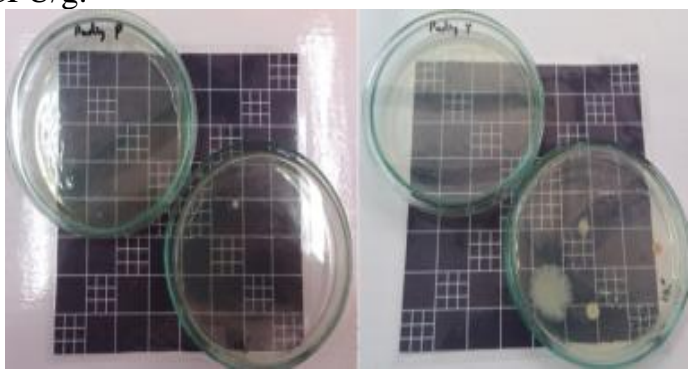

Gambar 6. Cawan analisis total mikroba, kapang dan khamir pada produk jelly jelentik 


\section{KESIMPULAN}

1. Produk jahe instan, manisan jahe dan jelly secara mikrobiologi aman karena memiliki nilai total mikroba, koliform, kapang dan khamir yang sesuai dengan sesuai dengan standar BPOM dan SNI.

2. Jus wornas memiliki total mikroba yang melampaui standar SNI dan jumlah kapang \& khamir melewati batas standar BPOM maupun SNI.

3. Semua produk posdaya Mawar Setu yang dianalisis bebas dari bakteri koliform.

\section{SARAN}

1. Perlu penentuan ulang umur simpan jus wornas karena hasil analisis menunjukkan nilai total mikroba dan kapang khamir yang melewati standar.

2. Pelatihan sangat dibutuhkan terhadap personal yang membuat produk jus wornas atau produk yang memiliki kadar air tinggi seperti pelatihan sanitasi dan higienisitas serta cara produksi pangan olahan baik.

\section{DAFTAR PUSTAKA}

Antara SN. 2014. Sistem pengawasan mutu dan keamanan pangan: Pengolahan rebung bambu. Modul Pelatihan Lembaga Penelitian dan Pengabdian Masyarakat. Universitas Udayana, Bali.

Atma Y., Seftiono, S., Taufikurrohman, MR. 2015 Internal reinforcement yoghurt household industry: A new potential micro small enterprenuer (MSE) in Indonesia urban area. Proceeding Conference on AgriEnterprenuer, UPM. Malaysia.

Badan Pengawasan Obat dan Makanan (BPOM). 2008. Pengujian Mikrobiologi Pangan. Infopom, vol 9 (2): 1-11.

Badan Pengawasan Obat dan Makanan (BPOM). 2009. Penetapan Batas Maksimum Cemaran Mikroba dan Kimia dalam Makanan. Peraturan Kepala BPOM, Jakarta.

Badan Standarisasi Nasional. 1994. SNI-01-35521994 Jelly agar. Badan Standarisasi Nasional Indonesia, Jakarta.

Badan Standarisasi Nasional. 1995. SNI 01-37191995 Minuman Sari Buah. Badan Standarisasi Nasional Indonesia, Jakarta.

Badan Standarisasi Nasional. 1996. SNI-01-43201996 Serbuk Minuman Tradisional. Badan Standarisasi Nasional Indonesia, Jakarta

Faridah ND, Yasni S, Suswantinah A, Aryani GW. 2013. Pencirian Mutu Kimiawi dan Mikrobiologis Produk Bandrek Instan dan Sirup Buah Pala (Myristica fragrans). Jurnal Imu Pertanian Indonesia Vol 18 (1): 43-48.

Jay JM, Loessner MJ, Golden DA. 2006. Modern Food Microbiology. $7^{\text {th }}$ edition. Springer, USA.
Harigan, W. F. 1998. Laboratory Methods in Food Microorganisms. 3rd ed. Academic Press. San Diego.

Hijriy L, Krisno M, Muizzudin. 2015. Pengaruh pemberian sari jahe (Zingiber officinale) terhadap jumlah koloni bakteri pada ikan tongkol (Euthynnus affinis). Prosiding Seminar Nasional Pendidikan Biologi, Universitas Muhammadiyah Malang: Malang.

Kurniawati, E. 2013. Kualitas jelly kulit buah markisa (passiflora edulis var. flavicarpa) dengan variasi suhu dan waktu ekstraksi pektin. Fakultas Teknobiologi, Universitas Atmajaya Yogyakarta.

Maturin L, Peeler JT. 2001. Aerobic Plate Count. In: Bacteriological Analytical Manual Online. Center for Food Safety and Applied Nutrition. Washington DC (US): US Food and Drug Administration.

Nugraha, A. 2003. Pembuatan minuman agar sebagai upaya diversifikasi produk agar-agar [skripsi].Fakultas Perikanan dan Ilmu Kelautan, IPB.

Pratiwi. 2009. Formulasi, uji kecukupan panas, dan pendugaan umur simpan minuman sari wornas (wortel nanas) [skripsi]. Fakultas Teknologi Pertanian, IPB.

Ray B. 2000. Fundamental Food Microbiology. $2^{\text {nd }}$ Edition. CRC Press, USA.

Shewfelt, RL. 2014. Pengantar Ilmu Pangan. Penerbit Buku Kedokteran, Jakarta.

Sugiarto, Yuliasih I, Tedy. 2007. Pendugaan umur simpan bubuk jahe merah (Zingiber officinale var. rubrum). J. Tek. Ind. Pert. Vol. 17 (1): 7-11.

Susanto E, Agustini TW, Swastawati F, Surti T, Fahmi AS, Albar MF, Nafis NK. 2011. Pemanfaatan Bahan Alami Untuk Memperpanjang Umur Simpan Ikan Kembung (Rastrelliger Neglectus). Jurnal Perikanan (J. Fish. Sci.) Xiii (2): 60-69.

Suyono, H. dan Haryanto. 2013, Buku Pedoman Pembentukan dan Pembangunan Pos Pemberdayaan Keluarga POSDAYA. Balai Pustaka: Jakarta.

Syah, D. 2012. Pengantar Teknologi Pangan. IPB Press, Bogor.

Yodfiatfinda, Maulidian, Atma, Y. 2015. Posdaya (family empowerment): a concept of family entrepreneurship to boost rural area development in the west java provinceindonesia. Proceeding Conference on AgriEnterprenuer, UPM. Malaysia.

Yuriani. 2010. Teknologi pengolahan dan pengawetan jahe sebagai keterampilan guru SMK dalam upaya mengembangkan kewirausahaan sekolah. J. Inotek 14 (1): 8694 